\title{
Detection of bleomycin- like antitumor agent produced by Streptomyces spp. local isolates
}

\author{
تثخيص المضاد (بلومايسين) الشبيه المنتج بواسطة عزلات محلية لبكتريا \\ Streptomyces spp.
}

Asia J. Rweish

Rafid A. Abdul-karim**
Mohammed A. K. Ibrahim*

Mohammed R. Abdul-majeed*

Zahra K. Jawad

Biotechnology Research Center / AL-Nahrain University /Iraq

*Biotechnology department / AL-Nahrain University /Baghdad /Iraq

**AL-Khwarzimi College / Baghdad University/ Baghdad/ Iraq

Abstract

Ethyl acetate extracts of fermentation cultures of five local Streptomyces isolates SRY-3, SRY-25, 5b, 10, NS-38 were identified as inhibitors of plasmacytoma cell line. Concentration at $0.016 \mu \mathrm{g} / \mathrm{ml}$ of ethyl acetate extract of (SRY-3,SRY25,5b,10,NS-38) inhibited $(46 \%, 40 \%, 21 \%, 34 \%, 34 \%)$ of mouse plasmacytoma cells respectively, where as $0.5 \mu \mathrm{g} / \mathrm{ml}$ inhibited $(58 \%, 55 \%, 35 \%$, $33 \%, 36 \%$ ) of plasmacytoma cells .

Quantities analysis of crude extracts by using HPLC on the basis of their retention times showed that the values were $(4.3,4.4,4.86,4.83 \& 4.84) \mathrm{min}$. for SRY-3, SRY-25, 5b, 10,NS-38 respectively, while the retention time of standard antitumor compounds was $\mathbf{( 4 . 2 6 )} \mathbf{m i n}$. This suggests that unknown compound of SRY-3 extract contain bleomycin-like compound. Addition of standard bleomycin to crude extract of SRY-3 increased milliabsorbans unit (M.A.U.) from 0.49 to 1.4 . The concentration of bleomycin-like antitumor in fermentation broth of SRY-3 isolate was $3.441 \mu \mathrm{g} / \mathrm{ml}$.

The five Streptomyces isolates have moderate activity against gram-positive and gram-negative bacteria, while standard BLM have no activity. 
المستخلص

تم تثخيص مثبطات خلايا البلازماسايتوما فى مستخلصات الاثيل اسيتيت لخمس عزلات محلية لبكتيريا الستربتومايسس ، اذ لوحظ ان تركيز 0.016 مايكروغرام/ مل من مستخلص الاثيل اسيتيت للنواتج التخمرية

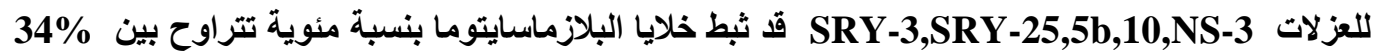
و 46\% على التوالى بينما ثبط تركيز 0.5 مايكروغرام/مل من المستخلص خلايا البلازماسايتوما بنسبة

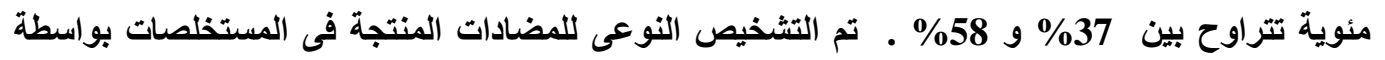
بالاعتماد على قراءة وقت القدرة الامتصاصية لكل مستخلص مقارنة مع البليومايسين ، حيث كانت

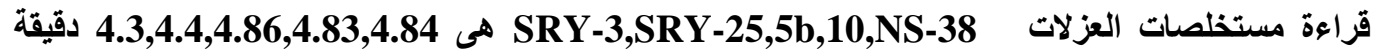
على التوالى ، بينما كاتت قراءة وقت القدرة الامتصاصية لمضاد البليومايسين النقى هى 4.26 دقيقة ـ توضح هذه النتائج ان المادة الفعالة فى مستخلص عزلة SRY-3 هو شبيه للبليومايسين النقى . وللتاكد من انتاجية العزلة SRY-3 لثبيه مضاد البليومايسين تم اضافة المضاد النقى الى المستخلص و وه مقارنة وحدة الامتصاصية المتناهية (M.A.U.) للمستخلص حيث كانت قبل الاضافة 0.4 و اصبحت 1.4 بعد اضافة البليومايسين النقى .

قدرت كمية المضاد الثبيه المنتج فى الوسط التخمرى بواسطة HPLC حيث كانت مساوية الى 3.4417 مايكروغرام/مل ـ أظهرت العزلات الخمس فعالية بايولوجية ضئيلة ضد كل من البكتريا الموجبة و السالبة

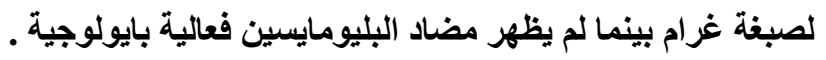

\section{Introduction}

Streptomycetes have considerable medical, biological and commercial importance [1], since they produce over $60 \%$ of known antibiotics and many other substances with valuable clinical and other applications [2]. Various antitumor compounds are produced by streptomycetes, which have activities against different types of tumor cells $[3,4,5]$. These drugs have been discovered as a result of screening protocols which should be rapid, reproducible, inexpensive and help to select compounds for advanced testing [6]. Natural products are screened for potential activity by determining the cytotoxicity of various dilutions of broths or extracts against tumor cell such as p388 mouse leukemia or B16 mouse melanoma cells [7]. The principle advantage of these methods is that they directly assay cytotoxicity against cancerous cell lines.

Bleomycin (BLM) is a glycopeptide antitumor drug produced by S.verticillus [8], has significant antitumor activity against several human malignancies $[9,10]$, and it has demonstrated a greater derree of 
potency against B16 mouse melanoma cells [11]. BLM is used in treatment of several diseases such as: testicular cancer, sequamous cell carcinoma and lymphoma [12]. However, differing from other antineoplastic drugs, BLMs characteristic of virtually no apparent bone marrow toxicity makes it suitable for the treatment of patients with poor bone marrow status [9]. The

\section{Materials and Methods}

\section{Microorganisms:}

Local isolates of Streptomyces SRY-3, SRY-25, 5b, 10, NS-38 were used throughout this work. These isolates were obtained from Iraqi soil. Staphylococcus aureus, Bacillus thurengensis and Escherichia coli were used to ascertain antimicrobial activity of Streptomyces isolates. Streptomyces isolates and test

\section{Fermentation and antitumor agents}

\section{extraction:}

Streptomyces isolates have been grown at $30^{\circ} \mathrm{C}$ in liquid production medium (S-medium) containing per liter: 10gm glucose; 4gm peptone; 4gm yeast extract; $0.5 \mathrm{gm} \mathrm{MgSO} 4.7 \mathrm{H} 2 \mathrm{O} ; 2 \mathrm{gm}$ KH2PO4; 4gm K2HPO4 [14]. Broth cultures were filtered; and extracted with ethyl acetate. The aqueous layer mechanism of BLM action has been attributed to DNA scission and fragmentation with inhibition of the usual DNA repair mechanisms; RNA and protein synthesis appear inhibited as well [13].

In this study an investigation was carried out for possible production of leomycin-like antitumour drug by local Streptomyces isolates.

microorganisms were obtained from the personal microbial collection of prof. Mohammed A.K.Ibrahim, Department of biotechnology; College of Science; AL - Nahrain University. Mouse plasmacytoma SU99 cell line was obtained from Biotechnology Research Center /AL-Nahrain University.

was then concentrated to dryness. The residue was dissolved in a small volume of methanol and the solution was applied to silica gel TLC chromatography [15] using mobile solvents of $10 \%$ ammonium acetate: methanol (1:1) [16]. Outline of extraction and purification procedure 
of the drug is shown in figure (1). The TLC spots, which represent standard bleomycin and crude eluents, were

\section{Cytotoxic activity assay:}

The assay was done by microtiter plates according to the method adopted by Abdul-Majeed, [17]. Ninety-six well tissue culture plates were used for this test to ensure the toxic effect of crude extract of fermentation culture broth of SRY-3, SRY-25, 5b, 10, NS38 on plasmacytoma SU 99 cell line. A $0.05 \mathrm{ml}$ of extract was added in the first and second wells of the first four lines. Two folds serial dilutions were made from the second well for the four lines which contain $0.05 \mathrm{ml}$ tissue culture medium (RPMI 199) till the twelfth well (in duplicate). The wells of the late four lines in the same plate were filled with $0.2 \mathrm{ml}$ tissue culture medium only considered as a control. A $0.15 \mathrm{ml}$ cell suspension of plasmacytoma cell culture $\left(10^{4}\right.$ cells per $\left.\mathrm{ml}\right)$ was added to

\section{Analysis of bleomycin by HPLC:}

The quantitative and qualitative assays of bleomycin were performed by high performance liquid chromatography (HPLC) the eluents were injected into the HPLC: column: shimi - pock

\section{Antimicrobial activity:}

Block assay method was used to determine the antimicrobial activity of Streptomyces isolates grown on scarped and eluted with methanol and dried for further investigation.

all wells of the plate. The culture plates were incubated at $37^{\circ} \mathrm{C}$ in humidified incubation with $5 \% \mathrm{CO}_{2}$ in air. The culturing plate was removed after 72 hours, and $0.05 \mathrm{ml}$ of $0.01 \%$ neutral red solution was added to each well, reincubated at $37^{\circ} \mathrm{C}$ for 2 hours, after incubation the medium was discarded, and the wells were washed with PBS. The results were recorded as following:

Viable cells will take the dye, while the dead cells will not, $0.1 \mathrm{ml}$ of phosphate; buffered-ethanol $\quad(0.1 \mathrm{M}$ $\mathrm{NaH}_{2} \mathrm{PO}_{4}$-ethanol; 1:1) was added to each well to elute the dye from the viable cells. The plate was read by micro ELISA reader at optical density of $492 \mathrm{~nm}$.

MRS-ODS, mobile phase (methanol: sodium acetate buffer) (0.1M), flow rate: $0.4 \mathrm{ml} / \mathrm{min}$, temperature: $25^{\circ} \mathrm{C}$ and detection at UV: 254-300 $\mathrm{nm}$.

Mueller - Hinton agar medium at 30

${ }^{\circ} \mathrm{C}[18]$. 


\section{Antibiotic Susceptibility:}

Antibiotic resistances of Streptomyces isolates were examined by using antibiotic sensitivity discs [19].

\section{Isolation procedure}

Fermentation broth

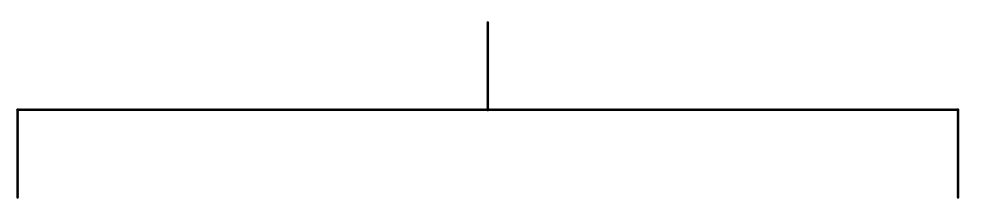

Filtrate $(300 \mathrm{ml})$

Mycelium discarded

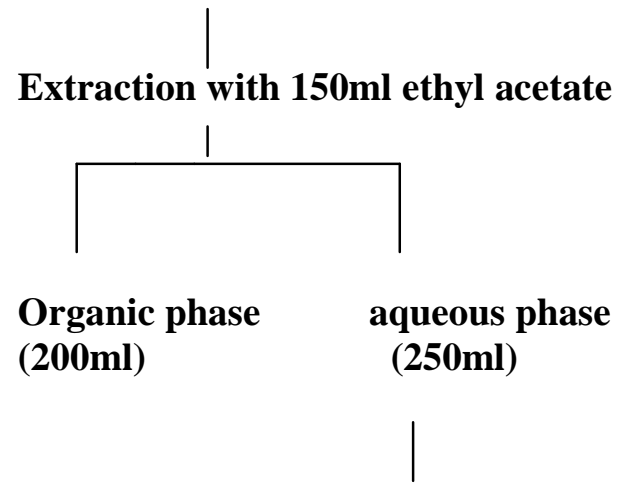

Crude extract

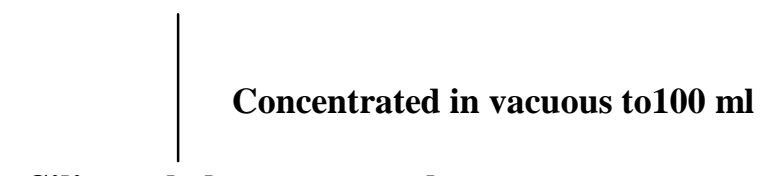

Silica gel chromatography

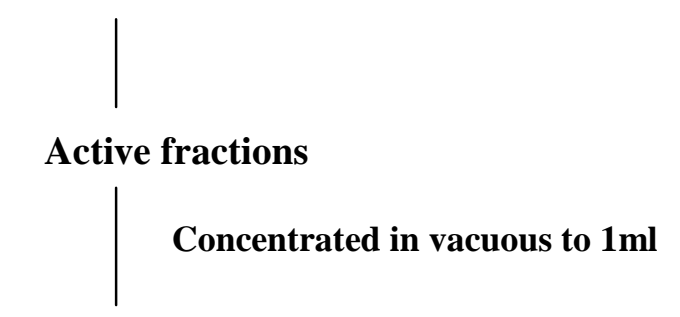

\section{Detected by HPLC}

Concentration of bleomycin- like compound of SRY-3 isolate $3.4417 \mu \mathrm{g} / \mathrm{ml}$

Figure 1: Extraction and purification of bioactive compound from local isolate of Streptomyces fermentation broth culture. 
Table 1: Cytotoxic effect of fermentation broth of Streptomyces local isolates on plasmacytoma cell line.

\begin{tabular}{|c|c|c|c|c|c|}
\hline \multirow{2}{*}{$\begin{array}{c}\text { Dose } \\
(\mathbf{M g} / \mathbf{m l})\end{array}$} & \multicolumn{5}{|c|}{ Inhibition \% } \\
\cline { 2 - 6 } & SRY-3 & SRY-25 & $\mathbf{5 b}$ & $\mathbf{1 0}$ & NS-38 \\
\hline 0.001 & 49 & 27 & 17.2 & 32.8 & 32.4 \\
\hline 0.002 & 45 & 20 & 17.9 & 33.1 & 32.8 \\
\hline 0.004 & 44 & 34 & 18.6 & 33.5 & 33.4 \\
\hline 0.008 & 49 & 32 & 19.3 & 33.5 & 33.5 \\
\hline 0.016 & 46 & 40 & 21 & 33.8 & 34.1 \\
\hline 0.031 & 44 & 46 & 20.7 & 33.1 & 34.8 \\
\hline 0.063 & 44 & 32 & 24.1 & 34.2 & 35.2 \\
\hline 0.125 & 46 & 40 & 24.5 & 34.2 & 35.2 \\
\hline 0.25 & 50 & 34 & 27.6 & 34.2 & 35.9 \\
\hline 0.5 & 58 & 55 & 34.5 & 32.4 & 36.2 \\
\hline
\end{tabular}

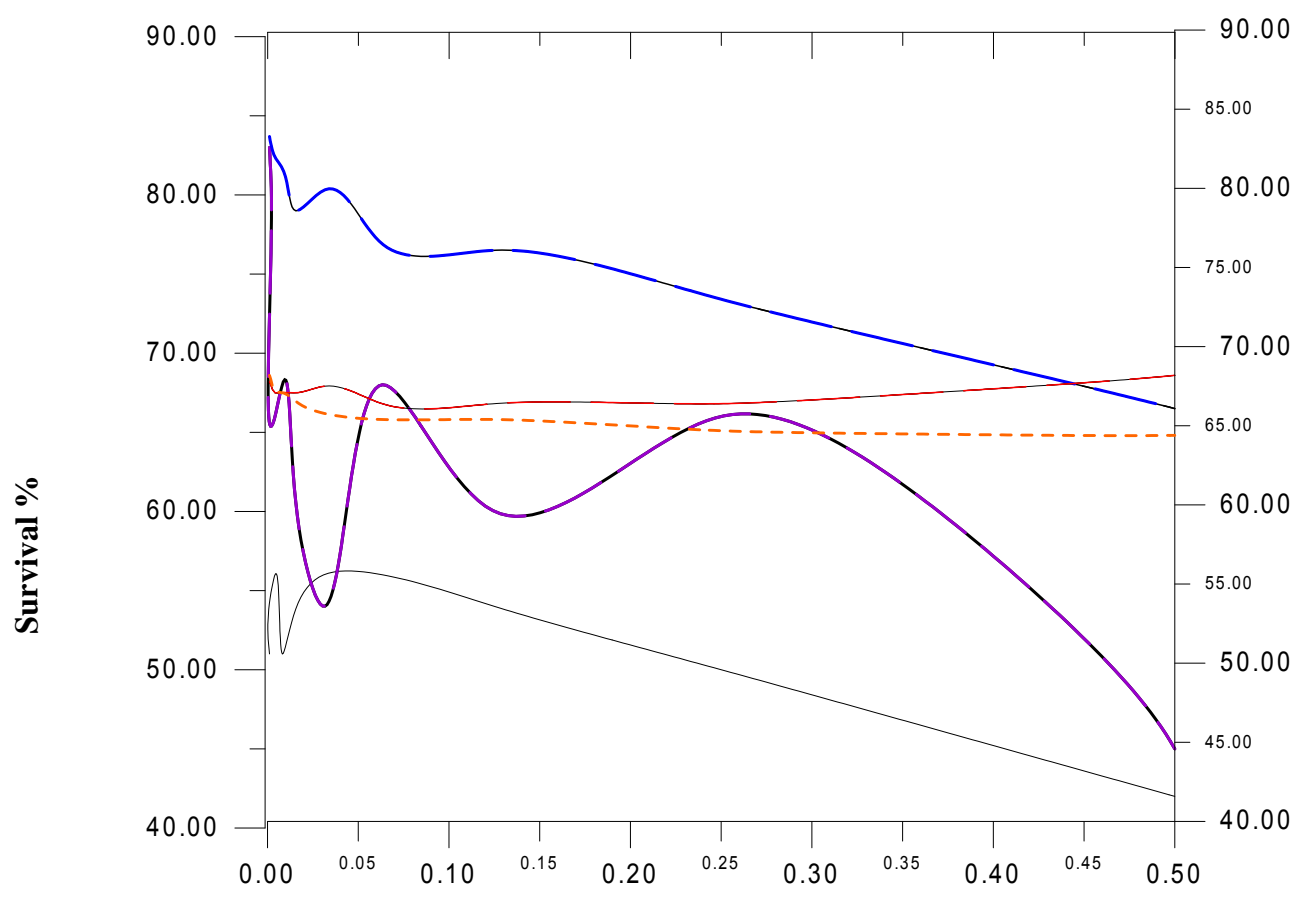

Concentration

$5 \mathbf{b}$
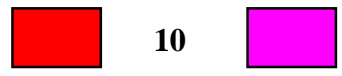

NS-38

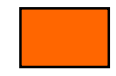

SRY-25

SRY-3

Figure 2: The inhibitory effect and survival of TLC fraction of Streptomyces local isolates on plasmacytoma cell line. 

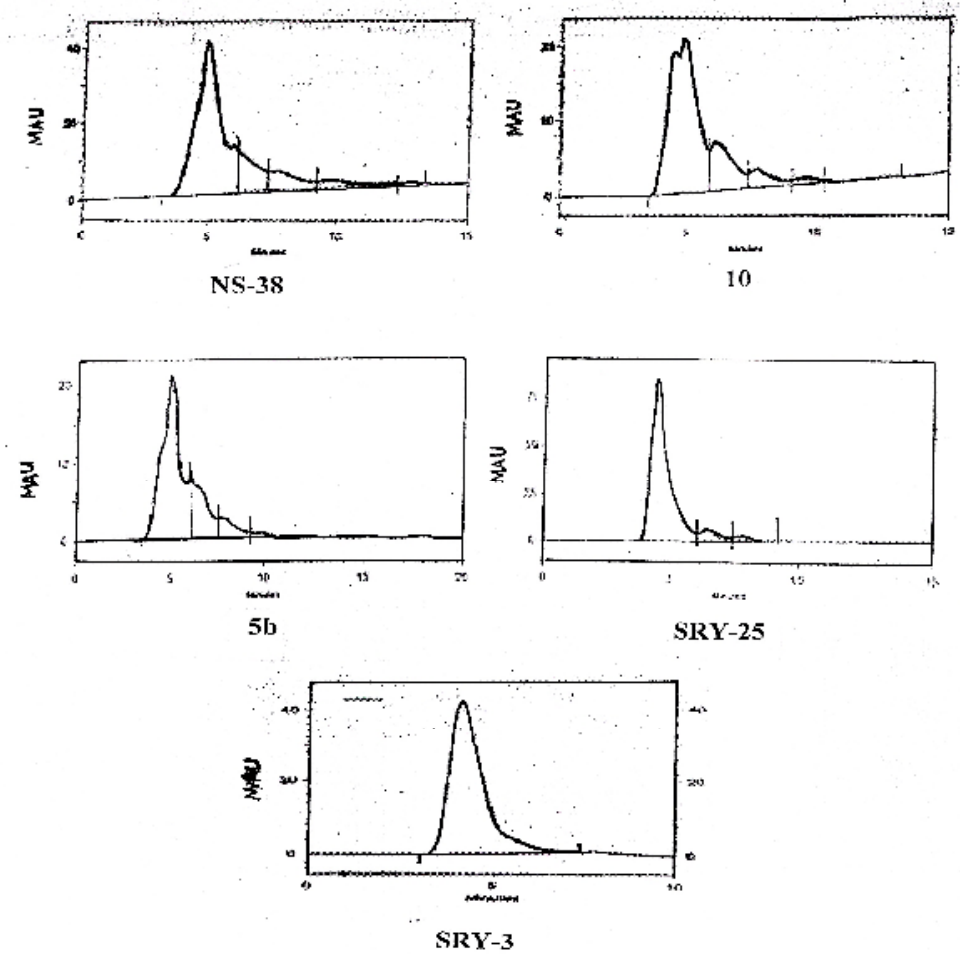

Figure 3: High performance liquid chromatography of local Streptomyces isolates.

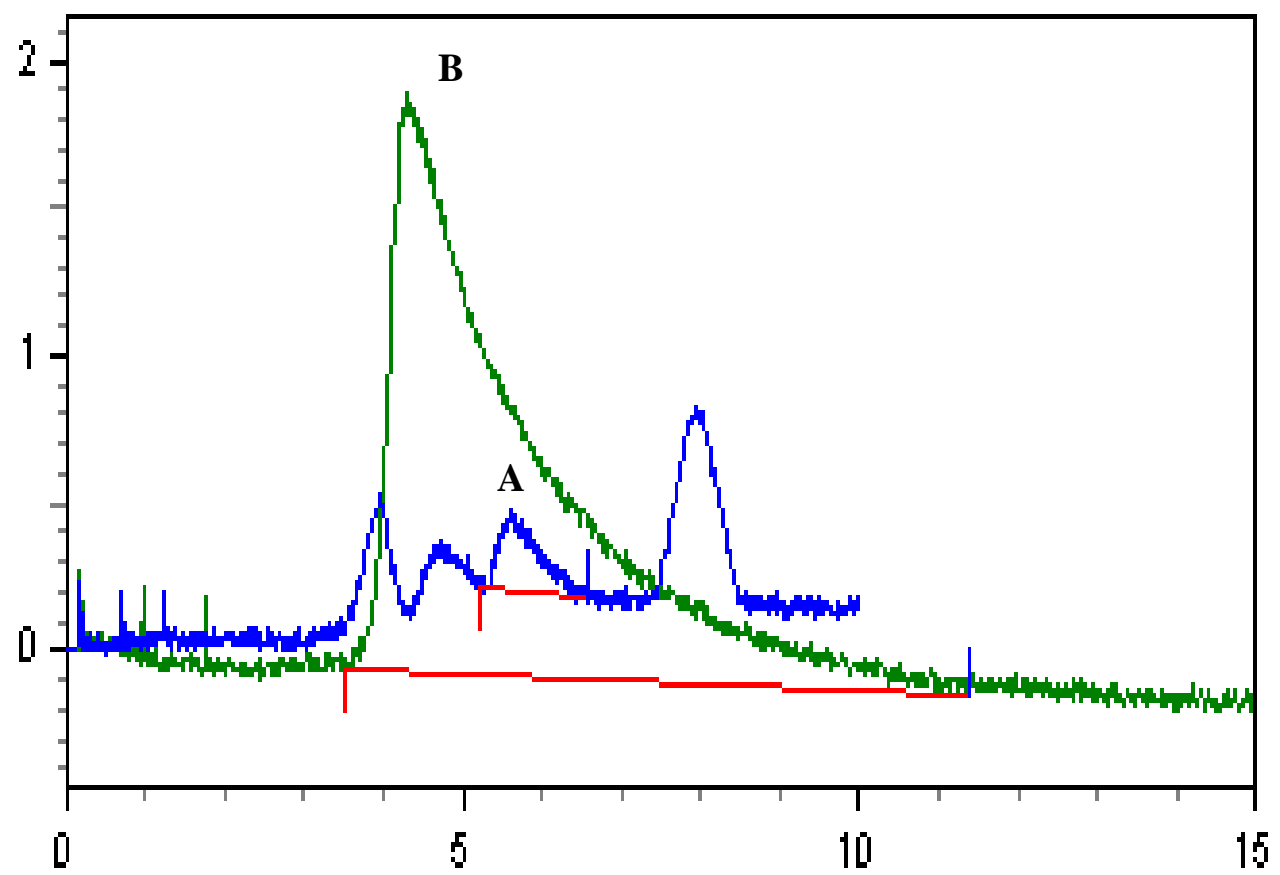

Figure 4: High performance liquid chromatography of TLC fraction of SRY-3 (A) and standard bleomycin (B). 


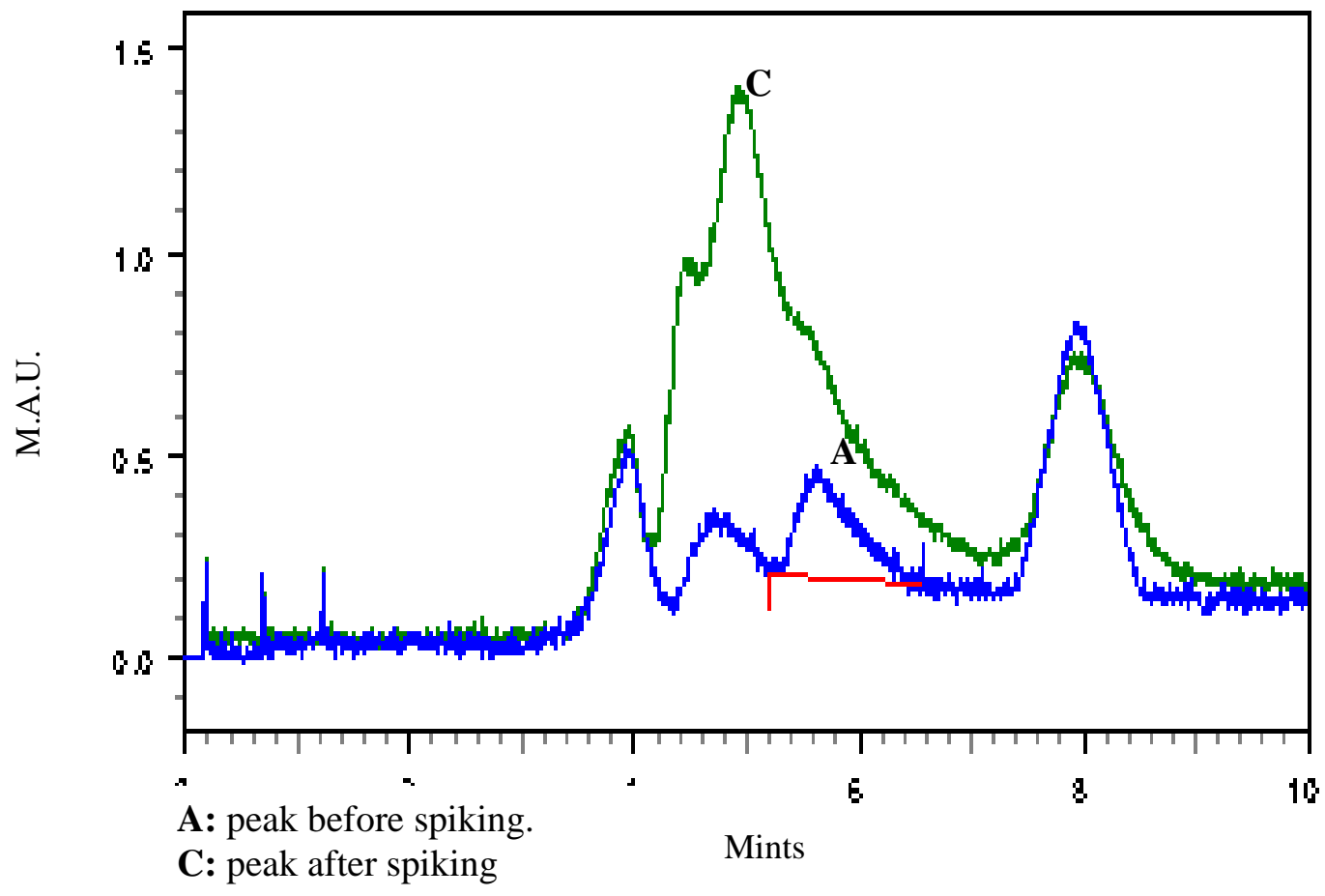

Figure 5: Spiking of TLC fraction of SRY-3 isolate with standard bleomycin.

Table 2: Antibiotic susceptibility of Streptomyces isolates.

\begin{tabular}{|l|c|c|c|c|c|c|}
\hline Antibiotics & $\begin{array}{c}\text { Concentration } \\
(\boldsymbol{\mu g} / \mathbf{d s c})\end{array}$ & \multicolumn{6}{|l|}{ Diameter of inhibition zone (mm) } \\
\cline { 3 - 7 } & $\mathbf{S R Y - 3}$ & $\mathbf{S R Y - 2 5}$ & $\mathbf{1 0}$ & $\mathbf{5 b}$ & $\mathbf{N S - 3 8}$ \\
\hline Tetracycline & 30 & $\mathrm{R}$ & $\mathrm{R}$ & $\mathrm{R}$ & $\mathrm{R}$ & $\mathrm{R}$ \\
\hline Erythromycin & 15 & 4 & 10 & 17 & $\mathrm{R}$ & $\mathrm{R}$ \\
\hline Streptomycin & 10 & 30 & 24 & 27 & 32 & 25 \\
\hline Gentamycin & 10 & 35 & 33 & 30 & 35 & 30 \\
\hline Chloramphenicol & 30 & 19 & $\mathrm{R}$ & $\mathrm{R}$ & $\mathrm{R}$ & $\mathrm{R}$ \\
\hline Ampicillin & 10 & $\mathrm{R}$ & $\mathrm{R}$ & $\mathrm{R}$ & $\mathrm{R}$ & $\mathrm{R}$ \\
\hline Rifampicin & 30 & 16 & 15 & $\mathrm{R}$ & $\mathrm{R}$ & $\mathrm{R}$ \\
\hline Lincomycin & 15 & $\mathrm{R}$ & $\mathrm{R}$ & 20 & $\mathrm{R}$ & 8 \\
\hline Carbenicillin & 100 & $\mathrm{R}$ & $\mathrm{R}$ & $\mathrm{R}$ & $\mathrm{R}$ & $\mathrm{R}$ \\
\hline Cephalosporin & 30 & $\mathrm{R}$ & $\mathrm{R}$ & $\mathrm{R}$ & $\mathrm{R}$ & $\mathrm{R}$ \\
\hline Bleomycin & 1500 & $\mathrm{R}$ & $\mathrm{R}$ & $\mathrm{R}$ & $\mathrm{R}$ & $\mathrm{R}$ \\
\hline
\end{tabular}




\section{Result:}

Mammalian cell cytotoxicity assay have been used to detect antitumor activity of natural products [20]. In this study plasmacytoma cell line technique was found as rapid and useful in screening for Streptomyces fermentation broths and their extracts.The cytotoxic activity of Streptomyces isolates SRY-3, SRY$25,5 \mathrm{~b}, 10 \& \mathrm{NS}-38$ crude extract was assayed on mouse plasmacytoma cell line in microtiter plate.

Table (1), shows the inhibitory effect of various concentrations of the SRY3, SRY-25, 5b, 10\&NS-38 TLC fractions on the growth of plasmacytoma cells as compared with the control.0.016 $\mathrm{g} / \mathrm{ml}$ of the above mentioned crude extracts, showed $(46 \%, 40 \%, 21 \%, 34 \%, 34 \%)$ inhibition of mouse plasmacytoma cells respectively, whereas $0.5 \mathrm{~g} / \mathrm{ml}$ showed $58 \%, 55 \%, 34.5 \%, 32.4 \%$ \& $36.2 \%$ inhibition of cells. These results suggest that the potency of $5 b$, 10 and NS-38 was lower than the potency of SRY-3 and SRY-25. Figure (2), shows the survival of mouse plasmacytoma cell line against TLC fraction of the five Streptomyces isolates.
Thus the results indicated that fermentation culture of SRY-3 isolate was superior and had showed greater degree of activity against tumor cell line. It is possible to suggest that the crude extract contained unknown active cytotoxic compound. In this regard, cytotoxic effects of Streptomyces fermentation broth was shown against human tumor cell lines [21].

The observed variation in the percentage of inhibition might due to difference in number of colonies in duplicate plates [22].

Fermentation broth cultures of SRY-3, SRY-25, 5b, 10\&NS-38 Streptomyces isolates were purified by following procedure shown in figure (1). Aqueous layer of each isolate and standard BLM were chromatographed on silica gel TLC plate. The objective of TLC method is for possible identification of bleomycin-like active antitumor compound produced in fermentation broth [23]. The UV exposure of standard BLM on TLC shows a spot with $0.68 \mathrm{Rf}$ value; the major spots of Streptomyces isolates extracts when exposed to UV lamp (286) showed violet color with $\mathrm{Rf}$ values of $0.67,0.67,0.64,0.66$ and 0.67 ) 
for SRY-3,SRY-25, 5b, 10\&NS-38 respectively.

In order to identify the active compound produced by Streptomyces isolates. TLC extracts of five Streptomyces isolates were subjected to HPLC techniques. The peaks were assigned on the basis of their retention time. Figure (3) shows the peaks of HPLC analysis of five TLC fractions with different retention times (4.3 min, $4.4 \mathrm{~min}, 4.86 \mathrm{~min}, 4.83 \mathrm{~min}$ and 4.84 min) for TLC fractions of SRY-3, SRY-25, 5b, 10\& NS-38 respectively; on the other hand retention time of standard bleomycin was $4.26 \mathrm{~min}$. figure (4).

The above results demonstrated that the reading of retention time of SRY-3 TLC extract was almost compatible with retention time of bleomycin drug, for more confirmation, TLC fraction of SRY-3 isolate spiked with standard bleomycin lead to an increase in milli

\section{References}

1. Chater K. F. and Bibb M. J. (1997). Regulation of bacterial antibiotic production. In Biotechnology,Vol.6, products of secondary Metabolism. pp. 57-105. Edited by $\mathrm{H}$. Keleinkauf and $\mathrm{H}$. von Dohren. Weinheim : VCH. absorbance unit of desired peak from 0.49 to 1.4 , figure (5). This result might further suggest that the produced antibiotic is bleomycin-like compound, with concentration about $3.4417 \mu \mathrm{g} / \mathrm{ml}$, in fermentation culture.

The susceptibility of Streptomyces isolates to various antibiotics was examined (table 2). The observed results indicated that all Streptomyces isolates were resistance to tetracycline, ampicillin, carbenicillin, cephalosporin and bleomycin; on the other hand all isolates was sensitive to streptomycin and gentamycin.

Antimicrobial activity of the filtrate of Streptomyces isolates were investigated; all Streptomyces isolates have moderate activity against grampositive and gram-negative bacteria While, standard BLM have no activity.

2. Bibb M. J.; Ward J. M. and Hopwood D.A. (1978). Transformation of plasmid DNA into Streptomyces at high frequency. Nature vol.274: 398 400.

3. Sngawara K. ; Hatori ; M. ; Nishiyama Y.; Tomita K. ; Kamei 
H.; Konishi M. and Oki T. (1990). Eponemycin, Anew antibiotic active agents B16 melanoma. J. of Antibio. Vol. XLII No.1: 8-18.

4. Mori H.; Funayama S.; Sudo Y.; Kamiyama K. and Omura S.(1990). Anew antibiotic, 13. Hydroyglucopiericidin A.J. of Antibio.Vol.43, No.10 pp.13291331.

5. Komiyama K.; Funayama S.; Anraku Y.;Ishibashi M.; Takahashi Y. and Omura S.(1990) . Novel antibiotics, Furaquincocina $\mathrm{A}$ and B. J. of Antibio.Vol.43, No.3, pp.247-252.

6. Goldin A. and Carter S.E. (1982): Screening and evaluation of antitumor agents. In Cancer Medicine. Ed., J. F. Holland and E.Frei III.,pp. 633-662, Lea and Febiger Co., Philadelphia.

7. Hakala M.T. and Rustum U.M. (1979): The potential value of in vitro screening. In Methods in Cancer Research. Vol. XVI. Ed., V.T. Devita and RH. Busch, pp.247-287, Academic press, New York.

8. Sugiyama M; Kumagai $T$; Hayashida M.; Maruyama M. and Matoba Y. (2002). The 1.6- $\mathrm{A}^{0}$ crystal structure of the Copper (11)- bound Bleomycin complexed with the bleomycin-binding protein from bleomycin producing Streptomyces verticillus. J.Biol. Chem. Vol.277, lssue 3, 2311 2320, January 18.

9. Blum R.H.; Carter S.K. and Agre K. (1973). A clinical review of bleomycin -A new antineoplastic agent. Cancer 31: 903- 914.

10. Crooks S.T. and Brander W.T. (1976). Bleomycin, a review. J. Med 7: 333428.

11. Hecht S.M. (2000). Bleomycin: new perspectives on the mechanism of action. Nat prod 63: $158-168$.

12. Salmon S. E. and Sartorelli A.C. (1998). Cancer chemotherapy, in Basic and Cinical pharmacology. (katzung, B. G., ed) Appleton - Lange, P. 881 - 911.

13. Suzuki H.; Nagai K.; Akutsu E.; Yamaki H. and Tanaka N. (1970): On the mechanism of action of bleomycin. Strand scission of DNA caused by bleomycin and it's binding to DNA in vitro. J. Antibio. 23(10): 473 480.

14. Shirling E.B. and Gpttlib D. (1966). Methods for characterization of Streptomyces 
species. Int. J.Sys.Bacteriol.16: 313-340.

15. Okabe T.; Shimazu A.; Hiroshi M.; Matsumura F.; Yamaguchi H.; Tanaka N. and Nishimura T.(1990). Resorthiomycin, a novel antitumor antibiotic: I. Taxonomy, Isolation and biological activity.

16. Weinstein M.J. and Wagman G.H. (1978). Antibiotics: Isolation, Separation and purfication. J.chromato.Lib.15: 718-739.

17. Abdul-Majeed, M.R. (2000). Induction and characterization of SU.99 plasmacytoma cell line and its effects on mice immune response. Ph.D thesis, submitted to the collage of science, Saddam University

18. Isaacson D.M. and Kirischaum J. (1986). Assay of Antimicrobial Arnold, L. D. and Nadine, A.S. (eds). American Society for Microbiology. Washimington, D.C.

19. Egorov N.S. (1985).Antibiotics, a scientific approach Mirpubishers.

Mirabelli C. K.: Bartus H.: Bartus J.O.L: Johnson R.: Mong S.M.
20. Sung C.P. and Crooke S.T.(1988) . Application of a tissue culture microtiter test for the 21. detection of cytotoxic agents from natural products. $J$. of Antibio. VOL.XXXVIII, No. 6,758-766.

22. Nishimura M.: Hirohisa $N$.; Hidenori N. ; Yasuhiro H. ; Masami E. ; Toshio G. and Masakuni O. (1988). A new antitumor antibiotic, FR900840, I. Discovery, Identification, Isolation and Characterization. J. Of Antibiotics: APR ć542.

23. Suzuki H. Tahara M. Takahashi M. Matsumura F. Okari T. Shimazu A. Hirata A. Yamaki H. Yamaguchi H. Tanaka N. and Nishimura $\mathrm{T}$. (1990). Resorthiomycin, a novel antitumor antibiotic. I-Taxonomy, isolation and biological activity. J.Antibio. 43:129-134.

24. Issaq H.J.; Barr E.W.; Wel T.; Meyers C. and Aszalos A. (1977). Thin-layer chromatographic classification of antibiotics exhibiting antitumor properties. J. of Chromatography, 133:291-301 